\title{
EFFECT OF SILICON ON SOMATIC EMBRYOGENESIS AND SHOOT REGENERATION OF DRY DATE PALM (PHOENIX DACTYLIFERA L.) CV BARTAMUDA
}

\author{
Abo El Fadl, Reda E. \\ Tissue Culture Unit, Department of Genetic Resources, Ecology and \\ Dry Land Agriculture Division, Desert Research Center, Cairo, Egypt \\ E-mail: redaaboelfadl@yahoo.com
}

\begin{abstract}
Q ilicon $(\mathrm{Si})$ has not been observed as an essential element $\checkmark$ for plant growth, however, the beneficial effect of Si has been recognized in many plant species. The use of $\mathrm{Si}$ is one of the important recent trends for improving embryogenesis, growth traits and morphological characters in the field of tissue culture, for using on a commercial scale. Therefore, in this study the effect of potassium silicate $\left(\mathrm{K}_{2} \mathrm{SiO}_{3}\right)$ and sodium silicate $\left(\mathrm{Na}_{2} \mathrm{SiO}_{3}\right)$ at different concentrations $(0.0,0.5,1.0,2.0,4.0$ and 8.0 $\mathrm{mg} / \mathrm{l})$ were examined on somatic embryogenesis and regeneration percentage of dry date palm cv Bartamuda In the light of the obtained results, treatment with $\mathrm{Si}$ had a positive effect. The highest percentage of somatic embryogenesis formation and callus degree was obtained on Murashige and Skoog (MS) medium supplemented with $4.0 \mathrm{mg} / 1 \mathrm{~K}_{2} \mathrm{SiO}_{3}$ from embryogenic callus derived from shoot tip explants. Moreover, this medium gave the highest number of embryos/culture and the lowest degree of browning and hyperhydricity. However, the highest mean length of embryo was obtained on MS medium supplemented with 2.0 $\mathrm{mg} / \mathrm{l} \mathrm{K}_{2} \mathrm{SiO}_{3}$ compared with other treatments. Fresh and dry weight of embryo increased linearly with increasing concentration of $\mathrm{Si}$ treatments of both $\mathrm{K}_{2} \mathrm{SiO}_{3}$ and $\mathrm{Na}_{2} \mathrm{SiO}_{3}$. The highest germination percentage was obtained with embryos that matured on MS medium supplemented with $8.0 \mathrm{mg} / 1 \mathrm{~K}_{2} \mathrm{SiO}_{3}$ or $\mathrm{Na}_{2} \mathrm{SiO}_{3}$. To our knowledge, this is the first study on the in vitro application of Si on dry date palm.
\end{abstract}

Keywords: In vitro, embryo formation, shoot tip, leaf primordial, potassium silicate, sodium silicate

Date palm (Phoenix dactylifera $\mathrm{L}$.) is one of the oldest fruit crops mainly cultivated in North Africa, Middle East, Near of Asia and some dispersed areas of Europe and America (Zaid, 2002 and Haider et al., 2013). 
Palm groves were planted from offshoots, which were produced by the date palm trees in the early part of their life. However, this traditional method is relatively slow to establish new date palm plantations, since a limited number of offshoots are produced by the tree during its lifespan. In addition, seed-propagated plants do not bear true type fruits due to heterozygosis and require up to seven years to reach the adulthood fruiting stage (Othamni et al., 2009). Propagation of date palm through in vitro techniques presents an efficient alternative for the conventional methods (Quiroz-Figueroa et al., 2006). Since 1970, intensive efforts have been undertaken into large-scale micropropagation of date palm using techniques such as somatic embryogenesis and organogenesis (Singh and Shekhawat, 2009).

Somatic embryogenesis, which differentiates the embryos from somatic cells, not acolyte has been widely used as it has too many advantages (Carlos and Martinez, 1998). Somatic embryogenesis can be a promising technique for in vitro propagation of the plants (Iyyakkannu et al., 2012). Palms are considered as a recalcitrant species to be used in tissue culture. Thus, the in vitro regeneration of date palm using somatic embryogenesis still requires more refined and optimized protocols (Chen and Chang, 2002). Browning of in vitro cultured explants is a frequent problem in date palm micropropagation. This phenomenon was encountered during somatic embryogenesis and leads to explants death (Abohatem et al., 2011). Hyperhydricity is a common physiological disorder in date palm somatic embryogenesis (McCubbin and Zaid, 2007). Browning and hyperhydricity phenomena considered as a major physiological problems for date palm tissue culture, resulting in deterioration and failure of tissue to be continued in growth and development. Browning and vitrification of regenerated plantlets severely affected the survival rate. Moreover, some serious physiological disorders were reported to decrease the proliferation capacity of shoot buds and to affect the quality of the multiplied plants resulting in hyperhydricity, tissue browning, and/or precocious rooting of organogenic cultures (Al-Khateeb, 2008 and Ruffoni and Savona, 2013). The composition of a culture medium has often been modified to stimulate the growth of particular plant material. In general, plant tissue culture medium composed of inorganic nutrients, organic supplements, carbon source, plant growth regulators and a solidifying agent. Mineral nutrients are necessary for growth and development of plants, the optimization of inorganic nutrients in the culture medium improves growth and morphogenesis of plant cells, tissue and organs in vitro. Several physiological disorders, such as browning, hyperhydricity, fasciations and shoot tip necrosis are often associated with the concentration of inorganic nutrients in the culture medium (Reed et al., 2013).

Egyptian J. Desert Res., 64, 65-82 (2014) 
Silicon ( $\mathrm{Si}$ ) is the second most abundant mineral element both on the surface of the Earth's crust and in the soil. It plays an important role in enhancing the resistance of plants to a biotic and biotic stresses such as drought, frost, metal toxicity, nutrient imbalance, salinity, and diseases (Ma, 2004). Although Si is beneficial for plant growth, it plays a vital role as a physicomechanical barrier in most plants. Despite its deposition on cell walls (Marschner, 1995), its active involvement in a multitude of physiological and metabolic processes is also evident (Moussa, 2006). It has not been included in any commercial tissue culture media formulation. The inclusion of Si to the culture medium improved the morphogenetic potential of plant cells, tissues and organs. Recent studies have shown the beneficial effects of $\mathrm{Si}$ in plant tissue culture. Si treatment significantly affected the antioxidant enzyme activities in many plants. Antioxidant enzymes enhanced the growth and morphogenesis (Liang et al., 2007). Addition of Si to the shoot induction medium significantly increased SOD, POD, APX, CAT activity in regenerated shoot buds as compared with the control (Iyyakkannu and Jeong, 2014).The activity of antioxidant enzymes increased during organogenesis in Brassica rapa (Abbasi et al., 2011). Several studies proved that the inclusion of $\mathrm{Si}$ to the tissue culture medium enhances callus growth, shoot regeneration and root induction, stimulates somatic embryogenesis, and improves morphological, anatomical and physiological characteristics of plantlets. In addition, Si treatment prolongs the longevity of calli and organs with a potential for plant regeneration. In vitro culture is a useful system for studying physiological and biochemical functions of $\mathrm{Si}$ in plants at a molecular level (Iyyakkannu and Park, 2014). Further studies on a wide variety of plant species are needed to confirm the role of $\mathrm{Si}$ in plant tissue culture. The objective of this study was to determine the effect of Si on in vitro production of date palm embryos in terms of the number of embryos produced and effect on embryos browning, hyperhydricity and germination.

\section{MATERIALS AND METHODS}

\section{Plant Material and Sterilization}

Explants preparation and embryos induction of date palm cv Bartamuda was used according to procedures described by Abo El-Fadl (2008). The offshoots were obtained from date palm trees, of 3-5 year-old and weighing from 20-35 kg, grown at Al-Aakab-Bahri region, $20 \mathrm{~km}$ from Aswan Governorate. Explants (shoot tips and leaf primordia) were surface sterilized under complete aseptic conditions by soaking in a Clorox bleach solution $5.25 \%$ sodium hypochlorite $(\mathrm{NaOCl})$ contained two drops of tween20 per $100 \mathrm{ml}$ solution (double surface sterilization), firstly by dipping the explants in $3 \% \mathrm{NaOCl}$ for 30 minutes in a transfer hood with gentle 
agitation, followed by three sequential rinses for one minute in sterile distilled water. Afterwards, explants were immersed in $0.1 \%$ mercuric chloride $\left(\mathrm{HgCl}_{2}\right)$ solution for 10 minutes, then rinsed three times with sterile distilled water, followed by $2 \% \mathrm{NaOCl}$ for 15 minutes and finally rinsed thoroughly with sterile distilled water. Shoot tips; 5-10 mm long, and leaf primordia were cut into three to four parts.

\section{Culture Medium}

Murashige and Skoog (MS) medium (Murashige and Skoog, 1962) (Duchefa, Haarlem, Netherlands) was the basal nutrient medium in the present study. MS medium was supplemented with growth regulators [dichloropenoxy acetic acid (2, 4-D), 2-iso pentenyl adenine (2iP), naphthalene acetic acid (NAA) and indole-3-butyric acid (IBA), according to each growth stage], in addition to $40 \mathrm{mg} / \mathrm{l}$ adenine sulphate, $170 \mathrm{mg} / \mathrm{l}$ sodium dihydrogen phosphate $\left(\mathrm{NaH}_{2} \mathrm{PO}_{4}\right)$ (Sigma cell culture, min. $90 \%$, St. Louis, USA), $30 \mathrm{~g} / \mathrm{l}$ sucrose, $3 \mathrm{~g} / \mathrm{l}$ activated charcoal, $100 \mathrm{mg} / \mathrm{l}$ ascorbic acid, 150 $\mathrm{mg} / \mathrm{l}$ citric acid and gelled with $2.5 \mathrm{~g} / \mathrm{l}$ phytagel. (Duchefa, Haarlem, Netherlands. The $\mathrm{pH}$ of the medium was adjusted to 5.7-5.8 before autoclaving at a pressure of $1.06 \mathrm{~kg} / \mathrm{cm}^{2}$ at $121^{\circ} \mathrm{C}$ for $15 \mathrm{~min}$.

\section{Callus Induction}

All surface sterilized explants were cultured in full-strength basal MS medium supplemented with $100 \mathrm{mg} / 1$ 2,4-D and $3 \mathrm{mg} / \mathrm{l} 2 \mathrm{iP}$. All cultures were incubated in a culture room at $27 \pm 2^{\circ} \mathrm{C}$ under complete darkness with regular transfer to fresh medium of the same composition every four weeks.

\section{Embryogenic Callus Induction}

After eight months, well-grown callus induced from explants were selected to subculture on MS medium supplemented with $10 \mathrm{mg} / \mathrm{l}$ 2, 4-D, 5 $\mathrm{mg} / \mathrm{l} \mathrm{NAA}$ and $5 \mathrm{mg} / \mathrm{l} 2 \mathrm{iP}$. Cultures were incubated in darkness and recultured three times onto the same fresh medium every four weeks.

\section{Somatic Embryos Formation and Maturation}

Embryogenic callus obtained from cultures was segmented $(1.0 \mathrm{~g})$ and cultured on MS medium containing $0.1 \mathrm{mg} / \mathrm{l} \mathrm{NAA}$ with various concentrations of potassium silicate $\left(\mathrm{K}_{2} \mathrm{SiO}_{3}\right)$ or sodium silicate $\left(\mathrm{Na}_{2} \mathrm{SiO}_{3}\right)$ $(0.0,0.5,1.0,2.0,4.0$, and $8.0 \mathrm{mg} / \mathrm{l})$. Each treatment consisted of nine completely randomized replicates, each replicate contained three samples and the cultures were incubated at $27 \pm 2^{\circ} \mathrm{C}$ with 16 -hours photoperiod under cool white florescent tubes. After eight weeks, percentage of somatic embryo formation (\%) and degree of callus growth were recorded. 
For maturation of somatic embryos, they were transferred individually onto the same medium composition and incubated under the same conditions. Mean number of embryos, mean length of embryo, degree of hyberhydricity, and degree of browning were recorded after 12 weeks of culturing. Degree of browning and hyperhydricity were determined according to the rate of scalling of Pottino (1981). Rating scale was; (0-1) negative result (1-2) below average result (2-3) average result (3-4) above average result (4-5) high result. Fresh and dry weight of embryo were also recorded as $\mathrm{g}$ from 20 replicates after 18 weeks of culturing. Dry weight of the embryo was obtained after drying in an oven at $40^{\circ} \mathrm{C}$ for at least 48 hours, until a constant weight was obtained.

\section{Germination of Somatic Embryos}

The percentage of the embryos that germinated in response to $\mathrm{K}_{2} \mathrm{SiO}_{3}$ or $\mathrm{Na}_{2} \mathrm{SiO}_{3}$ at different concentrations $(0.0,0.5,1.0,2.0,4.0$ and 8.0 $\mathrm{mg} / \mathrm{l}$ ) were calculated based on the total embryos regenerated in each treatment. This germination test excluded treatments that regenerated a total of less than 40 somatic embryos. For rooting enhancement, the regenerated embryos were transfered on MS medium supplemented with $2 \mathrm{mg} / \mathrm{l} \mathrm{IBA}$ and acclimatized on pots containing a mixture of peat and perlite (1:1).

\section{Experimental Design and Statistical Analysis of Data}

The experiments were subjected to completely randomized design. Analysis of variance (ANOVA) and Duncan's multiple range test (Duncan, 1955), as modified by Snedecor and Cochran (1982), were performed to analyze the obtained data. The differences among averages of the recorded parameters for all treatments were tested for significance at 5\% level. Averages followed by the same letter are not significantly different at $p<0.05$.

\section{RESULTS AND DISCUSSIUN}

Effect of $\mathrm{K}_{2} \mathrm{SiO}_{3}$ and $\mathrm{Na}_{2} \mathrm{SiO}_{3}$ on somatic embryogenesis and callus growth is presented in table (1). A white nodular embryogenic callus (1.0 g), which was obtained after three subcultures on the callus induction medium, was separated from the primary callus cultures and transferred onto fresh medium supplemented with $0.1 \mathrm{mg} / \mathrm{l} \mathrm{NAA}$ and various concentrations of $\mathrm{K}_{2} \mathrm{SiO}_{3}$ or $\mathrm{Na}_{2} \mathrm{SiO}_{3}(0.0,0.5,1.0,2.0,4.0$ and $8.0 \mathrm{mg} / \mathrm{l})$. Callus continued to proliferate, increased in mass and began to develop globular somatic embryos. Concerning the effect of type of explant, data clearly show that the highest significant value of somatic embryos formation percentage of $60.4 \%$ was observed with embryogenic callus obtained from shoots tip (Fig. 
1a), compared with the embryo formation percentage of embryogenic callus obtained from leaf primordial, which produced a lower value of $56.5 \%$.

These results are in line with those obtained by several researchers (Matter, 1986, 1987; Azra et al., 1997 and Madhuri et al., 1998). They obtained nodular and embryogenic callus cultures of date palm by culturing shoot tips and leaf primordia. Dass et al. (1989) induced callus from shoot tip explants of date palm cv "Muscat", also, Bhansali and Kaul (1991) obtained nodular callus from shoot explants of date palm cvs "Halawy", "Khadrawy", "Shamran" and "Zahidi" Hervan et al. (1991) reported that five different explants of date palm cvs "Kabkab" and "Estameran" were cultured on medium with different growth regulators. Juvenile leaf explants were able to form callus in five types of culture media. The highest rate of callus formation was obtained with shoot tip explants. Regarding to the effect of $\mathrm{Si}$ treatments, data revealed that $4.0 \mathrm{mg} / 1 \mathrm{~K}_{2} \mathrm{SiO}_{3}$ gave the highest percentage of somatic embryos from embryogenic callus obtained from both shoot tips and leaf primordia (92.3 and $77.8 \%$, respectively). Also this medium gave the highest significant value of callus growth degree (3.7) compared to the other $\mathrm{K}_{2} \mathrm{SiO}_{3}$ treatments. Whereas the same concentration of $\mathrm{Na}_{2} \mathrm{SiO}_{3}(4.0 \mathrm{mg} / \mathrm{l})$ gave 70.4 and $66.7 \%$ of somatic embryos from embryogenic callus obtained from shoot tips and leaf primordia, respectively. While $2.0 \mathrm{mg} / \mathrm{I} \mathrm{Na}_{2} \mathrm{SiO}_{3}$ gave the highest percentage of embryos formation of 81.5 and $74.4 \%$ for embryogenic callus produced from shoot tips and leaf primordia, respectively, and also the highest callus growth degree of 3.3 comparing to the other concentrations of $\mathrm{Na}_{2} \mathrm{SiO}_{3}$. Moreover, increasing the concentration of $\mathrm{K}_{2} \mathrm{SiO}_{3}$ or $\mathrm{Na}_{2} \mathrm{SiO}_{3}$ to $8.0 \mathrm{mg} / \mathrm{l}$ gave significantly the lowest value of embryogenic callus formation percentage produced from both explants as compared with the other Si concentrations. On the other hand, the lowest significant value of somatic embryos formation and callus degree for both explant types were recorded on MS medium without Si. As a conclusion, findings suggested that the percentage of embryo formation and callus growth degree were increased gradually with increasing Si concentration, while the higher concentration of $8.0 \mathrm{mg} / \mathrm{l}$ resulted in reduced somatic embryos production, but even at this concentration, production of embryos remained higher than that of control. The inclusion of Si to the culture medium improved the morphogenetic potential of plant cells, tissues and organs. It was previously reported that the inclusion of $\mathrm{Si}$ to the culture medium enhances callus growth and stimulates somatic embryogenesis (Iyyakkannu and Park, 2014). Addition of $\mathrm{Si}$ as sodium silicate $\left(\mathrm{Na}_{2} \mathrm{SiO}_{3}\right)$ to the modified MS medium promotes the growth of calli of Phragmites australis and stimulates embryogenesis of root calli (Mathe et al., 2012). 
Also, the addition of $\mathrm{Si}$ to culture medium has been proven to be advantageous for callus induction in rice (Islam et al., 2005)

Table (1). Effect of $\mathrm{K}_{2} \mathrm{SiO}_{3}$ or $\mathrm{Na}_{2} \mathrm{SiO}_{3}$ on percentage of embryos formation and degree of callus growth from embryogenic callus derived from shoot tip and leaf primordia of Bartamuda date palm cultivar. Data recorded after eight weeks of culturing.

\begin{tabular}{cccc}
$\begin{array}{c}\text { Treatments } \\
(\mathbf{m g} / \mathbf{l})\end{array}$ & \multicolumn{2}{c}{ Percentage of embryos formation (\%) } & $\begin{array}{c}\text { Degree of } \\
\text { callus growth }\end{array}$ \\
\cline { 1 - 3 } $\mathbf{K}_{\mathbf{2}} \mathbf{S i O}_{3}$ & Shoot tips & Leaf primordia & \\
0.0 & $37.0 \mathrm{f}$ & $29.6 \mathrm{e}$ & $1.8 \mathrm{c}$ \\
0.5 & $59.3 \mathrm{~d}$ & $55.6 \mathrm{~d}$ & $1.8 \mathrm{c}$ \\
1.0 & $66.7 \mathrm{c}$ & $59.3 \mathrm{c}$ & $2.1 \mathrm{~b}$ \\
2.0 & $70.4 \mathrm{~b}$ & $70.4 \mathrm{~b}$ & $2.2 \mathrm{~b}$ \\
4.0 & $92.3 \mathrm{a}$ & $77.8 \mathrm{a}$ & $3.7 \mathrm{a}$ \\
8.0 & $44.4 \mathrm{e}$ & $55.6 \mathrm{~d}$ & $1.9 \mathrm{c}$ \\
$\mathbf{N a}_{2} \mathbf{S i O}_{3}$ & & & \\
0.0 & $37.0 \mathrm{f}$ & $29.6 \mathrm{f}$ & $1.8 \mathrm{e}$ \\
0.5 & $59.3 \mathrm{~d}$ & $55.6 \mathrm{~d}$ & $2.1 \mathrm{~d}$ \\
1.0 & $66.7 \mathrm{c}$ & $59.3 \mathrm{c}$ & $2.4 \mathrm{c}$ \\
2.0 & $81.5 \mathrm{a}$ & $74.4 \mathrm{a}$ & $3.3 \mathrm{a}$ \\
4.0 & $70.4 \mathrm{~b}$ & $66.7 \mathrm{~b}$ & $2.6 \mathrm{~b}$ \\
8.0 & $40.7 \mathrm{e}$ & $40.7 \mathrm{e}$ & $1.8 \mathrm{e}$ \\
$\begin{array}{c}\text { Mean of } \\
\text { explant type }\end{array}$ & 60.4 & 56.5 & \\
\hline
\end{tabular}

Means within a column followed by the same letters are not significantly different at $\mathrm{P}<0.05$.

In this study, somatic embryos were observed through the incubation period on MS medium supplemented with $0.1 \mathrm{mg} / \mathrm{l} \mathrm{NAA}$ and the different concentrations of $\mathrm{K}_{2} \mathrm{SiO}_{3}$ or $\mathrm{Na}_{2} \mathrm{SiO}_{3}$. Embryos were white in color, advanced globular in shape and appeared individually or in cluster. From data in table (2), it is clear that the mean number, and length of embryos, and the degree of browning and hyperhydricity were all affected by $\mathrm{K}_{2} \mathrm{SiO}_{3}$ or $\mathrm{Na}_{2} \mathrm{SiO}_{3}$ concentration (Fig. 1b). Concerning the mean number of embryos/culture, the best result was recorded on MS medium supplemented with $4.0 \mathrm{mg} / 1 \mathrm{~K}_{2} \mathrm{SiO}_{3}$ compared with the other $\mathrm{K}_{2} \mathrm{SiO}_{3}$ concentrations, where it was 9.1 embryos/culture, while the concentration of $2.0 \mathrm{mg} / 1 \mathrm{Na}_{2} \mathrm{SiO}_{3}$ gave $8.2 \mathrm{embryos} /$ culture. As well as, increasing $\mathrm{Si}$ concentration to $8.0 \mathrm{mg} / \mathrm{l}$ decreased embryos number. On the other hand, the mean embryo length was affected also by $\mathrm{Si}$ concentration, it ranged from 2.9 to $5.4 \mathrm{~cm}$ at concentrations lower than $8.0 \mathrm{mg} / \mathrm{l}$,compared to the control treatment, where 
it was $1.6 \mathrm{~cm}$. Increasing $\mathrm{Si}$ concentration to $8.0 \mathrm{mg} / \mathrm{l}$ decreased the mean embryo length. MS medium supplemented with $2.0 \mathrm{mg} / 1 \mathrm{~K}_{2} \mathrm{SiO}_{3}$ was found to be the best medium to improve the mean length of embryo, which reached $5.4 \mathrm{~cm}$. Although, for $\mathrm{Na}_{2} \mathrm{SiO}_{3}$, its concentration of $1.0 \mathrm{mg} / \mathrm{l}$ gave the highest mean length of embryos of $4.9 \mathrm{~cm}$. As reported by Bairu and Kane (2011), several physiological problems associated with the micropropagation such as browning, hyperhydricity and shoot necrosis are often encountered during the different stages of micropropagation.

Table (2). Effect of different concentrations of $\mathrm{K}_{2} \mathrm{SiO}_{3}$ or $\mathrm{Na}_{2} \mathrm{SiO}_{3}$ on mean number and length of embryos/culture and degree of browning and hyperhydricity of embryos of Bartamuda date palm cultivar. Data were taken after 12 weeks of culturing.

\begin{tabular}{ccccc}
\hline $\begin{array}{c}\text { Treatments } \\
(\mathbf{m g} / \mathbf{l})\end{array}$ & $\begin{array}{c}\text { Mean } \\
\text { number of } \\
\text { embryos/culture }\end{array}$ & $\begin{array}{c}\text { Mean } \\
\text { length of } \\
\text { embryo } \\
\text { /culture }\end{array}$ & Browning & $\begin{array}{c}\text { Degree* } \\
\text { Hyper- } \\
\text { hydricity }\end{array}$ \\
\hline $\mathbf{K}_{2} \mathbf{S i O}_{3}$ & & & & \\
0.0 & $3.3 \mathrm{f}$ & $1.6 \mathrm{e}$ & $1.8 \mathrm{a}$ & $2.3 \mathrm{a}$ \\
0.5 & $4.1 \mathrm{~d}$ & $2.9 \mathrm{c}$ & $1.0 \mathrm{~b}$ & $1.7 \mathrm{~b}$ \\
1.0 & $5.3 \mathrm{c}$ & $3.7 \mathrm{~b}$ & $0.8 \mathrm{c}$ & $1.2 \mathrm{c}$ \\
2.0 & $7.1 \mathrm{~b}$ & $5.4 \mathrm{a}$ & $0.6 \mathrm{~d}$ & $0.8 \mathrm{e}$ \\
4.0 & $9.1 \mathrm{a}$ & $3.9 \mathrm{~b}$ & $0.3 \mathrm{e}$ & $0.5 \mathrm{f}$ \\
8.0 & $3.8 \mathrm{e}$ & $2.3 \mathrm{~d}$ & $0.6 \mathrm{~d}$ & $0.9 \mathrm{~d}$ \\
$\mathbf{N a}_{2} \mathbf{S i O}_{3}$ & & & & \\
0.0 & $3.3 \mathrm{f}$ & $1.6 \mathrm{f}$ & $1.8 \mathrm{a}$ & $2.3 \mathrm{a}$ \\
0.5 & $4.1 \mathrm{~d}$ & $2.9 \mathrm{~d}$ & $1.0 \mathrm{~b}$ & $1.5 \mathrm{~b}$ \\
1.0 & $5.1 \mathrm{c}$ & $4.9 \mathrm{a}$ & $0.8 \mathrm{c}$ & $1.2 \mathrm{c}$ \\
2.0 & $8.2 \mathrm{a}$ & $4.2 \mathrm{~b}$ & $0.6 \mathrm{~d}$ & $0.8 \mathrm{~d}$ \\
4.0 & $6.8 \mathrm{~b}$ & $3.2 \mathrm{c}$ & $0.4 \mathrm{f}$ & $0.6 \mathrm{e}$ \\
8.0 & $3.6 \mathrm{e}$ & $2.1 \mathrm{e}$ & $0.5 \mathrm{e}$ & $0.8 \mathrm{~d}$ \\
\hline
\end{tabular}

Means within a column followed by the same letters are not significantly different at $\mathrm{P}<0.05$

* Rating scale: (1) negative result (2) below average result (3) average result (4) above average result (5) high result.

The highest degrees of browning and hyperhydricity were obtained on MS medium free of $\mathrm{Si}$ (control) comparing with the media containing $\mathrm{K}_{2} \mathrm{SiO}_{3}$ or $\mathrm{Na}_{2} \mathrm{SiO}_{3}$ (Fig. 1b). Much lower degrees of browning and hyperhydricity were recorded with all Si concentrations, they decreased with the increasing of $\mathrm{Si}$ concentration until reaching $4.0 \mathrm{mg} / \mathrm{l}$. It appears that the level of $\mathrm{Si}$ as element in the form of $\mathrm{K}_{2} \mathrm{SiO}_{3}$ or $\mathrm{Na}_{2} \mathrm{SiO}_{3}$ could possibly play

Egyptian J. Desert Res., 64, 65-82 (2014) 
an important role in reducing browning and hyperhydricity incidence. Addition of $\mathrm{Si}$ to the culture medium reduced hyperhydricity in Ornithogalum dubium (Ziv, 2010). Phenolic oxidative tissue browning is one of the bottlenecks in woody plant tissue culture. In guava, tissue browning was completely prevented by sealing the nodal explants cutting ends with $\mathrm{Si}$ (Youssef et al., 2010). Addition of $\mathrm{Si}$ as $\mathrm{K}_{2} \mathrm{SiO}_{3}$ to $\mathrm{MS}$ medium reduced the hyperhydricity in Cotoneaster wilsonii plant by decreasing the content of MDA in the regenerated shoots when compared with the control (Sivanesan et al., 2011). Duan et al. (2013) suggested that Si treatment improved the survival rate of grape "Kyoho and Koshu Sanjaku" calli under low temperature by preventing browning. Also, Agarie et al. (1998) reported that $\mathrm{Si}$ prevent the structural and functional deterioration of cell membranes when rice plants are exposed to environmental stress and that it may also be involved in the thermal stability in cell membranes. Liang et al. (2003) found that $\mathrm{Si}$ treated plants had decreased membrane lipid peroxidation, leading to greater membrane stability under stress. Mathe et al. (2012) reported that Si has a significant effect of somatic embryo development in reed. It can be concluded from the current study that the problem of hyperhydricity and browning can be reduced by the inclusion of $\mathrm{Si}$ to the culture medium.

Results shown in table (3) indicate that the addition of $\mathrm{K}_{2} \mathrm{SiO}_{3}$ or $\mathrm{Na}_{2} \mathrm{SiO}_{3}$ increased significantly both fresh and dry weights of embryos. The highest fresh and dry weights of embryos were achieved at $8.0 \mathrm{mg} / \mathrm{l}$ of $\mathrm{K}_{2} \mathrm{SiO}_{3}$, which gave 0.85 and $0.38 \mathrm{~g}$, respectively, compared to the other $\mathrm{K}_{2} \mathrm{SiO}_{3}$ treatments. Also, the same concentration of $\mathrm{Na}_{2} \mathrm{SiO}_{3}(8.0 \mathrm{mg} / \mathrm{l})$ gave 0.72 and $0.29 \mathrm{~g}$ of fresh and dry weights, respectively. On the other hand, the lowest fresh and dry weights of embryos were obtained on $0.5 \mathrm{mg} / \mathrm{l}$ of both $\mathrm{K}_{2} \mathrm{SiO}_{3}$ and $\mathrm{Na}_{2} \mathrm{SiO}_{3}$ and were gradually increased with increasing their concentrations from 0.5 to $8.0 \mathrm{mg} / \mathrm{l}$. Supplementation of the MS medium with $\mathrm{K}_{2} \mathrm{SiO}_{3}$ was found to be most effective for both fresh and dry weights of embryos. Also, it was observed that the moisture content of embryo decreased gradually throughout the maturation regime. Somatic embryos were reduced to $40 \%$ of its moisture content with $8.0 \mathrm{mg} / \mathrm{K} \mathrm{K}_{2} \mathrm{SiO}_{3}$ (data not presented).

There is a positive effect of $\mathrm{Si}$ on growth by producing the greatest biomass yield of four grasses and corn (Eneji et al., 2008 and Bakhat et al., 2009). The effect of silicon on tissue strength is by preventing the structural and functional deterioration of cell membranes (Agarie et al., 1998). Addition of Si significantly increased fresh and dry weights of shoot and root of Ajuga multiflora as compared with the control. The highest fresh and dry weights of shoot and root were obtained on the MS medium containing 3.6 $\mathrm{mM} \mathrm{Si}$ as reported by Iyyakkannu and Jeong (2014). Braga et al. (2009) investigated the effect of different $\mathrm{Si}$ sources such as $\mathrm{CaSiO}_{3}, \mathrm{~K}_{2} \mathrm{SiO}_{3}$ and 
$\mathrm{Na}_{2} \mathrm{SiO}_{3}$ on the growth of strawberry "Oso Grande' seedling. The fresh and dry weights of seedlings increased in MS medium containing $\mathrm{NaSiO}_{3}$. Seedlings of Banana "Maca" cultured in the medium supplemented with $\mathrm{Na}_{2} \mathrm{SiO}_{3}$ increased length, fresh and dry weight of shoots (Asmar et al., 2011). Many studies have suggested the positive growth effects of silicon, including increased dry mass and yield (Korndorfer and Lepsch, 2001). Also, Singh et al. (2006) reported the increased dry matter and yield in rice by Si application. Shoot dry matter of cotton plants increased three folds with Si application as compared to the control (Aziz et al., 2001). Dry weight of stevia callus was increased with increasing of Si. The positive effect of Si on growth of stevia callus may be due to that it prevents the structural and functional deterioration of cell membranes (Agarie et al., 1998), also reduced osmolyte leakage and lipid peroxidation (Shen et al., 2010).

Table (3). Effect of different concentrations of $\mathrm{K}_{2} \mathrm{SiO}_{3}$ or $\mathrm{Na}_{2} \mathrm{SiO}_{3}$ on fresh and dry weight of somatic embryo of Bartamuda date palm cultivar. Data were taken after 18 weeks of culturing.

\begin{tabular}{ccc}
\hline \multirow{2}{*}{$\begin{array}{c}\text { Si treatments } \\
(\mathbf{m g} / \mathbf{l})\end{array}$} & $\begin{array}{c}\text { Fresh weight }(\mathbf{g}) \\
\text { of embryo }\end{array}$ & $\begin{array}{c}\text { Dry weight }(\mathrm{g}) \\
\text { of embryo }\end{array}$ \\
\cline { 2 - 3 } $\mathbf{K}_{\mathbf{2}} \mathrm{SiO}_{3}$ & $0.22 \mathrm{f}$ & \\
0.0 & $0.28 \mathrm{e}$ & $0.044 \mathrm{f}$ \\
0.5 & $0.42 \mathrm{~d}$ & $0.070 \mathrm{e}$ \\
1.0 & $0.50 \mathrm{c}$ & $0.130 \mathrm{~d}$ \\
2.0 & $0.54 \mathrm{~b}$ & $0.182 \mathrm{c}$ \\
4.0 & $0.85 \mathrm{a}$ & $0.214 \mathrm{~b}$ \\
8.0 & $0.22 \mathrm{f}$ & $0.383 \mathrm{a}$ \\
\hline $\mathbf{N a}_{2} \mathrm{SiO}_{3}$ & $0.24 \mathrm{e}$ & \\
0.0 & $0.35 \mathrm{~d}$ & $0.044 \mathrm{f}$ \\
0.5 & $0.39 \mathrm{c}$ & $0.060 \mathrm{e}$ \\
1.0 & $0.41 \mathrm{~b}$ & $0.113 \mathrm{~d}$ \\
2.0 & $0.72 \mathrm{a}$ & $0.140 \mathrm{c}$ \\
4.0 & & $0.154 \mathrm{~b}$ \\
8.0 & & $0.291 \mathrm{a}$ \\
\hline
\end{tabular}

Means within columns followed by the same letters are not significantly different at $\mathrm{P}<0.05$.

The ability to form plantlets in vitro strongly increased with increasing embryo maturation (Carmi et al., 1998 and Ragavan, 2003). Low efficiency of embryo maturation and germination and conversion to plantlets is a major problem in many species (Suhasini et al., 1996 and Vahdati et al., 
2008). Embryo maturation and simultaneous conversion to plantlets is one of the steps in somatic embryogenesis, which partially depends on the embryo quality (Iyyakkannu et al., 2012). In the present study, the germination of embryos was obtained by the four week of culturing in the regeneration medium that containing $\mathrm{K}_{2} \mathrm{SiO}_{3}$ or $\mathrm{Na}_{2} \mathrm{SiO}_{3}$ at different concentrations (Table 4).

Table (4). Effect of different concentrations of $\mathrm{K}_{2} \mathrm{SiO}_{3}$ or $\mathrm{Na}_{2} \mathrm{SiO}_{3}$ on germination of somatic embryos percentage of Bartamuda date palm cultivar.

\begin{tabular}{cc}
\hline Conc. $(\mathbf{m g} / \mathbf{l})$ & Embryo germination \% \\
\hline $\mathrm{K}_{2} \mathrm{SiO}_{3}$ & \\
0.0 & $52.5 \mathrm{f}$ \\
0.5 & $67.5 \mathrm{e}$ \\
1.0 & $70.0 \mathrm{~d}$ \\
2.0 & $80.0 \mathrm{c}$ \\
4.0 & $87.5 \mathrm{~b}$ \\
8.0 & $95.0 \mathrm{a}$ \\
\hline $\mathrm{Na}_{2} \mathrm{SiO}_{3}$ & \\
0.0 & $52.5 \mathrm{f}$ \\
0.5 & $62.5 \mathrm{e}$ \\
1.0 & $70.0 \mathrm{~d}$ \\
2.0 & $72.0 \mathrm{c}$ \\
4.0 & $75.0 \mathrm{~b}$ \\
8.0 & $90.0 \mathrm{a}$ \\
\hline
\end{tabular}

Means within columns followed by the same letters are not significantly different at $(\mathrm{P}<0.05)$.

The mature embryos showed a green color after three weeks of culturing. Then these embryos produced shoots and roots simultaneously. Germination of somatic embryos was observed in all tested treatments and the percentage of germination varied from 52.5 to $90 \%$. Data in table (4) show that the highest percentage of somatic embryos germination was observed at $8.0 \mathrm{mg} / 1 \mathrm{~K}_{2} \mathrm{SiO}_{3}$, followed by the same concentration of $\mathrm{Na}_{2} \mathrm{SiO}_{3}$, which gave 95 and 90\%, respectively (Fig. 1c and d). On the other hand, the medium without Si gave the lowest percentage of germination $(52.5 \%)$. The embryo germination percentage increased linearly with increasing concentration of $\mathrm{Si}$ in the medium. Germinated embryos produced good root and shoot systems when transferred to half-strength MS medium supplemented with $1 \mathrm{mg} / \mathrm{IBA}$ (Fig. e). They were developed into complete plantlets within four weeks, and then plantlets were acclimatized and successfully transferred to the soil mixture (Fig. f). Addition of Si to the 
culture medium promoted shoot regeneration, however the mechanism of $\mathrm{Si}$ action is not known. In general, Si treatment significantly affected the antioxidant enzymes activities in many plants (Ma, 2004 and Liang et al., 2003). Addition of Si to the shoot induction medium significantly increased SOD, POD <APX and CAT activity in regenerated shoot buds as compared with the control in Ajuga multiflora, similarly, the activity of antioxidant enzymes increased during organogenesis in Brassica rapa. (Abbasi et al., 2011), Caladium bicolor (Isah and Mujjb, 2011), Corocus sativus (Vatankhah et al., 2010), Piper nigrum (Ahmed et al., 2013) and Plum (Faize et al., 2013). Addition of $\mathrm{Si}$ is advantageous for callus induction and plant regeneration in rice (Islam et al., 2005). Recently, Mathe et al. (2012) reported that $\mathrm{Si}$ has a significant effect on somatic embryo development, plant and root morphogenesis of common reed.

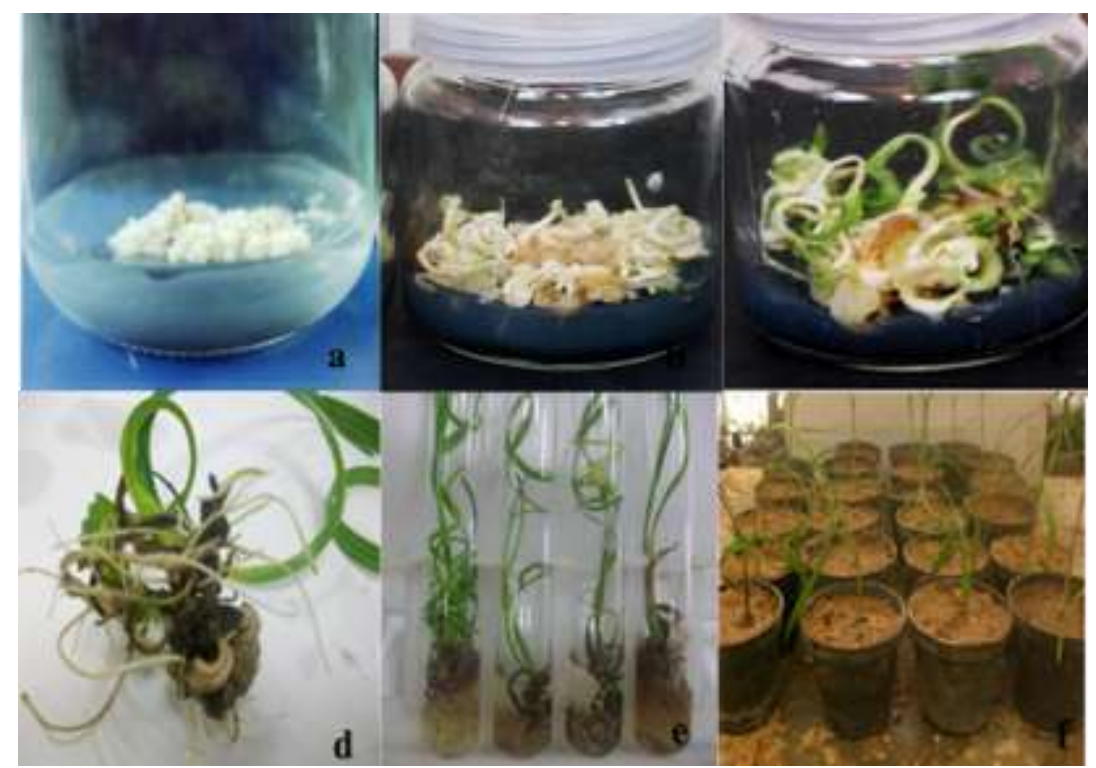

Fig. 1. Effect of silicon on somatic embryogenesis and shoot regeneration of Bartamuda dry date palm cultivar. (a) Embryogenic callus derived from shoot explants, (b) Embryos development with Si treatment (c and d) Germination of embryos on MS medium supplemented with 8 $\mathrm{mg} / \mathrm{l} \mathrm{K}_{2} \mathrm{SiO}_{3}$, and (e and f) Rooting and acclimatization.

In conclusion, addition of silicon as potassium silicate or sodium silicate to date palm culture medium had a positive effect in promoting embryos formation, increasing the number and length of embryos, increasing fresh and dry weights of embryo, improving germination of embryos and 
reducing the incidence of hyberhydricity and browning in plant cells. Therefore, Si enhances the morphogenesis mainly associated with culture medium and nutritional factors. The present study indicates the potential of this biotechnology based methodology for mass production of the dry date palm Bartamuda cultivar.

\section{ACKNOWLEDGEMENT}

The author is grateful to Associate Professor Dr. Ghada Abd ElMoneim Hegazi, Head of Tissue Culture Unit-Genetic Resources Department-Desert Research Center, for reviewing this manuscript.

\section{REFERENCES}

Abbasi, B.H., M. Khan, B. Guo, S.A. Bokhari and M.A. Khan (2011). Efficient regeneration and antioxidative enzyme activities in Brassica rapavar turnip. Plant Cell, Tissue and Organ Culture, 105 (3): 337-344.

Abo El-Fadl, R.E. (2008). Studies on in vitro propagation of Aswan date palm cultivars and their germplasm preservation. Ph.D. Thesis, Department of Plant Biotechnology, Genetic Engineering and Biotechnology Research Institute (GEBRI), Sadat City, Minufiya University, Egypt.

Abohatem, M., J. Zouine and I. El Hadrami (2011). Low concentrations of BAP and high rate of subcultures improve the establishment and multiplication of somatic embryos in date palm suspension cultures by limiting oxidative browning associated with levels of total phenols and peroxidase activities. Sci. Hort., 130: 344-348.

Agarie, S., N. Hanaoko, O. Ueno, A. Miyazaki, F. Kubota, W. Agata and P.B. Kaufman (1998). Effect of silicon on tolerance to water deficit and heat stress in rice plants (Oryza sativa L.) monitored by electrolyte leakage. Plant Prod. Sci., 1: 96-103.

Ahmed, N., H. Addasi, I. Rahman and H. Fazal (2013). Piper nigrum: micropropagation, antioxidative enzyme activities and chromatographic fingerprint analysis for quality control. Applied Biochemistry and Biotechnology, 169 (7): 2004-2015.

Al-Khateeb, A.A. (2008). The problems facing the use of tissue culture technique in date palm (Phønix dactylifera L.). Sci. J. King Faisal Univ., 9: 85-104.

Asmar, S.A., M. Pasqual, F.A. Rodrigues, A.G. Araujo, L.A.S. Pio and S.O. Silva (2011). Sources of silicon in the development of 
micropropagated seedlings of banana "Maca" Cienc. Rural, 41: 1127- 1131.

Aziz, T., M.A. Ou and I. Ahmed (2001). Differential growth response of cotton genotypes infected with root -rot to silicon nutrition. Pak. Soil Sci., 20: 101-108.

Azra, Q., H. Iqbal, A. Mushtaq, R. Hamid and L. Muhammad (1997). Sustained multiplication of long term embryogenic cultures of date palm and their field performance. Pakistan J. Botany, 29 (1): 135141.

Bairu, M.W and M.W. Kane (2011). Physiological and developmental problems encountered by in vitro cultured plants. Plant Growth Regulation, 63:101-103.

Bakhat, H.F., S. Hanstein and S. Schubert (2009). Optimal level of silicon for maize (Zea mays L. cv Amado) growth in nutrient solution under controlled condition. The Proceeding of the International Plant Nutration Colloquium XVI, Davis, CA.

Bhansali, R.R., and R.K. Kaul (1991). Into future, date through tissue culture. Indian Horticulture, 36 (3): 6-10.

Braga, F.T., C.F. Nunes, A.C. Favero, M. Pasqual, J.G. Carvalho and E.M. Castro (2009). Anatomical characteristics of the strawberry seedlings micropropagated using different sources of silicon. Pesqui. Agropecu. Bras., 44: 128 -132.

Carlos, M. and F.X. Martinez (1998). The potential uses of somatic embryogenesis in agroforestry are not limited to synthetic seed technology. Rev. Bras. Fis. Veg., 10: 1-12.

Carmi, F., F. De Pasquale and A.M. Puglia (1998). In vitro rescue of sour orange (Citrus aurantium L.) and their detection based on RFLP analysis. Plant Breed. 117: 261-266.

Chen J.T. and W.C. Chang (2002). Effect of tissue culture conditions and explants characteristics on direct somatic embryogenesis in Oncidium (Gower Ramzey). Plant Cell, Tissue and Organ Culture, 69: 41-44.

Dass, H.C., R.K. Kaul, S.P. Joshi and R.R. Bhansali (1989). In vitro regeneration of date palm plants. Current Science, 58 (1): 22-24 (c. f. Hort. Abst., 62 (5): 4425).

Duan, X., M. Tang and W. Wang (2013). Effects of silicon on physiology and biochemistry of Dendrobium moniliforme plantlets under cold stress. Agri. Biotechnol., 2: 18 -21.

Duncan, D.B. (1955). Multiple range and Multiple F tests. Biometrics, 11: $1-42$

Egyptian J. Desert Res., 64, 65-82 (2014) 
Eneji, A.E., S. Inanaga, S. Muranaka, J. Li, T. Hattori, P. An and W. Tsuji (2008). Growth and nutrient use in four grasses under drought stress as mediated by silicon fertilizers. J. Plant Nutr., 31: 355-365.

Faize, M., L. Faize and C. Petri (2013). Cu/Zn superoxide dismutase and ascorbate peroxidase enhance in vitro shoot multiplication in transgenic plum. Journal of Plant Physiology, 170 (7): 625 -632.

Haider, M.S., I.A., Khan, S.A. Naqvi, M.J. Jaskani and R.W. Khan (2013). Fruit development stages effects on biochemical attributes in date palm. Park. J. Agri. Sci., 50: 577-583.

Hervan, E.M., A.M. Shakib, M. Modiri, M. Afshari, S. Khoshkam and S. Nazeri (1991). Study of callus induction from in vitro culture of different parts of date palm. Seed and Plant, 7 (1-2): 9-13.

Isah, T. and A. Mujib (2011). Studies on antioxidant enzymes activity during in vitro morphogenesis of Caladium bicolor Linn. International Journal of Modern Cellular and Molecular Biology, 1 (1): $1-9$.

Islam, M., M. Ahmed and D. Mahaldar (2005). In vitro callus induction and plant regeneration in reed explants of rice (Oryza sativa L.). Res. J. Agri. Biol. Sci., 1: 72-75.

Iyyakkannu, S. and B.R. Jeong (2014). Silicon promotes adventitious shoot regeneration and enhances salinity tolerance of Ajuga multiflora Bunge by altering actitivity of antioxidant enzyme. The Scientific World Journal, Article ID 521703.

Iyyakkannu, S. and S.W. Park (2014). The role of silicon in plant tissue culture. Frontiersin Plant Science, 5: 1- 4.

Iyyakkannu, S., S. Moon, J. Sonali and R.J. Byoung (2012). Secondary somatic embryogenesis in Crocus vernus (L.) HILL. Propagation of Ornamental Plants, 12: 163-170

Korndorfer, G.H. and I. Lepsch (2001). Effect of silicon on plant growth and crop yield. In: Silicon in Agriculture : Studies in Plant Science, 8: $115-131$.

Liang, Y., Q. Chen, Q. Lui, W. Zhang and R. Ding (2003). Exogenous silicon $(\mathrm{Si})$ increases antioxidant enzyme activity and reduces lipid peroxidation in roots of salt -stressed barley (Hordeum vulgare L .). Journal of Plant Physiology, 160 (10): 1157 -1164.

Liang, Y., W. Sun, Y. Zhu, and P. Christie (2007). Mechanisms of silicon mediated alleviation of a biotic stresses in higher plants a review. Environmental Pollution 147: 422-428

Ma, J.F. (2004). Role of silicon in enhancing the resistance of plants to biotic and a biotic stresses. Soil Science and Plant Nutrition, 50: 11-18. 
Madhuri, S.P. Shanker and N. Sharon (1998). Somatic embryogenesis and plant regeneration from primordial leaf of Phoenix dactylifera $\mathrm{L}$. cv Yakubi. Indian J. Experimental Biology, 36 (5): 526-529.

Marschner, H. (1995). In "Part I. Nutritional Physiology". Mineral Nutrition of Higher Plants. Marschner H. (ed.). Academic Press, London. $2^{\text {nd }}$ ed. 18-30, 313-363.

Mathe, C., A. Mosolygo, G. Suranyi, A. Beke, Z. Demeter and V.R. Toth (2012). Genotype and explants-dependent morphogenesis and silicon response of common reed (Phragmites australis) tissue cultures. Aquat. Bot., 97: 57-63.

Matter, AA. (1986). In vitro propagation of Phoenix dactylifera L. Date Palm Journal, 4: 137-152.

Matter, AA. (1987). Production and cryogenic freezing of date palm germplasm and regeneration of plantlets from frozen materials, Iraq J. Agric. Sci., 5: 35-49.

McCubbin, MJ. and A. Zaid (2007). Would a combination of organogenesis and embryogenesis techniques in date palm micropropagation be the Answer?. Acta Hort., 736: 255-259.

Moussa, H.R. (2006). Influence of exogenous application of silicon on physiological response of salt-stressed maize (Zea mays L.). Int. J. Agric. Biol., 2: 293-297.

Murashige, T. and F. Skoog (1962). A revised medium for rapid growth and bioassays with tobacco tissue culture. Physiologia Plantarum, 15 (3) $473: 96-497$.

Othmani, A., C. Bayoudh, N. Drira, M. Marrakchi and M. Trifi (2009). Somatic embryogenesis and plant regeneration in date palm (Phoenix dactylifera L.) cv Boufeggous is significantly improved by fine chopping and partial desiccation of embryogenic callus. Plant Cell, Tissue and Organ Culture, 97: 71-79.

Pottino, BG. (1981). In "Methods in Plant Tissue Culture”. Dep. Hort. Agric. Collage Maryland Univ., Collage Park, Maryland USA, p. 8-29.

Quiroz-Figueroa, FR, R. Rojas-Herrera, R.M., Galaz-Avalos and VM. Loyola-Vargas (2006). Embryo production through somatic embryogenesis can be used to study cell differentiation in plants. Plant Cell, Tissue and Organ Culture, 86: 285-301.

Ragavan, V. (2003). One hundred years of zygotic embryo culture investigation. In Vitro Cell Dev. Biol. Plant, 39: 437 - 442.

Reed, B.M., S .Wada, J. Denoma and R.P. Niedz (2013). Mineral nutration influences physiological responses of pear in vitro. In Vitro Cell. Dev. Biol. Plant, 49: 699-709.

Egyptian J. Desert Res., 64, 65-82 (2014) 
Ruffoni, B. and M. Savona (2013). Physiological and biochemical analysis of growth abnormalities associated with plant tissue culture. Hort. Environ. Biotechnol., 54:191-205.

Shen, X., Y. Zhou, L. Duan, Z. Li, A.E. Eneji and J. Li (2010). Silicon effects on photosynthesis and antioxidant parameters of soybean seedlings under drought and ultraviolet-B radiation. J. Plant Phys., 167: 1248 -1252.

Sing, M. and N. Shekawat (2009). In "Tissue Culture of Date Palm (Phoenix dactylifera L.) A Non-conventional Approach”. Kumar, A. and Shekhawat (ed.). Plant Tissue Culture and Molecular Markers: Their Role in Improving Crop Productivity. IK International Pvt Ltd, New Delhi.

Sivanesan, L., J.Y. Song, S.J. Hwang and B.R. Jeong (2011). Micropropagation of Cotoneaster wilsonii Nakai a rare endemic ornamental plant. Plant Cell, Tissue and Organ Culture, 105: 55 $-63$.

Singh, K., R. Singh, J.P. Singh, Y. Singh and K.K. Singh (2006). Effect of level and time of silicon application on growth, yield and its uptake by rice (Oryza sativa L.). Indian J. Agric. Sci., 76: 410413.

Snededor, G.W. and W.G. Cochran (1982). In "Statistical Methods". $7^{\text {th }}$ ed. Iowa State Univ. Press Ames. Iowa, USA.

Suhasini, K., A. Sagare and P. Krishnamurthy (1996). Study of aberrant morphogenesis and lack of conversion of somatic embryos of chickpea (Cicer arietinum L.). In Vitro Cell Dev. Bio., 32: 6-10.

Vahdati, K., S. Bayat, E. Hassan, M. Jaritech and M . Mirmasoumi (2008). Effect of exogenous ABA on somatic embryo maturation and germination in Persian walnut (Juglans regia L.). Plant Cell Tiss. Org. Cult., 93: 163-171.

Vatankhah, E., V. Niknam and H. Ebrahimzadeh (2010). Activity of antioxidant enzyme during in vitro organogenesis in Crocus sativus. Biologia Plantarum, 54 (3): 509 -514.

Youssef, M.A., M.R. El-Helw, A.S. Taghian and H.M. El-Aref (2010). Improvement of Psidium guajava L. using micropropagation. Acta Hort., 894: 223-230.

Zaid, A. (2002). In "Date Palm Cultivation". United Nations FAO Plant Production and Protection. Rome. 156, Rev. 1.

Ziv, M. (2010). Silicon effects on growth acclimatization and stress tolerance of bioreactor cultured Ornithogalum dubium plants. Acta Hort., 852: 29-36. 


\title{
تأثير السليكون على نمو وتكثف الأجنة الخضرية في نخيل البلح الجاف برتف صنف برتمودا
}

\author{
رضا السيد أبو الفضل
}

وحدة زر اعة الأنسجة، قسم الأصول الور اثية، مركز بحوث الصحر اء، المطرية، القاهرة،

\section{مصر}

على الرغم من أن عنصر السليكون لم يدرج ضمن العناصر الأساسية لنمو النباتات إلا انه إنه

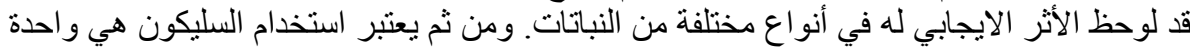

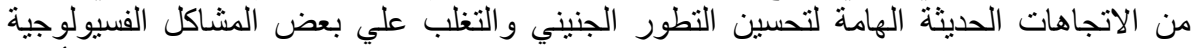

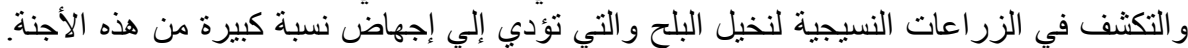

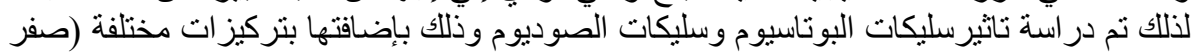

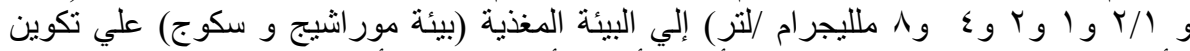

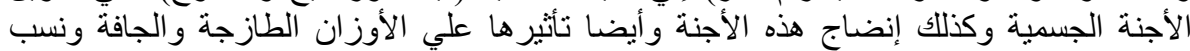

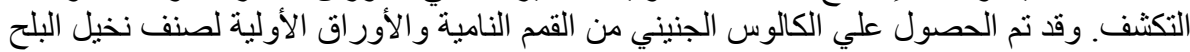

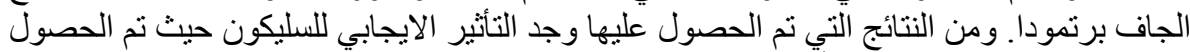

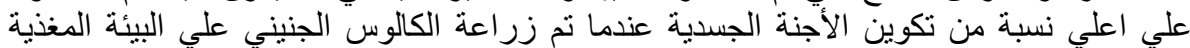

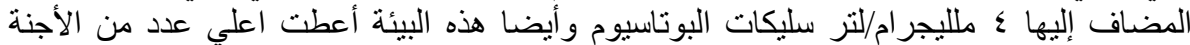

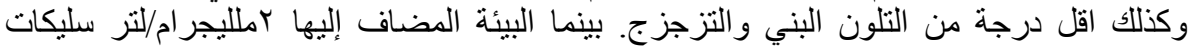

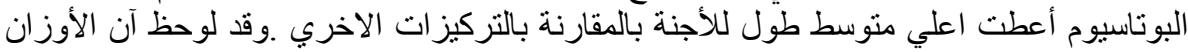

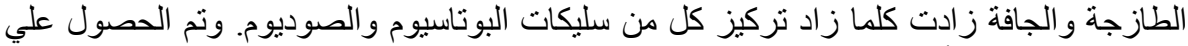

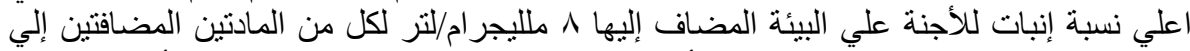

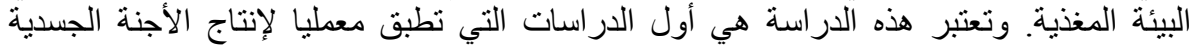
لصنف نخيل البلح الجاف برتمودا.

Egyptian J. Desert Res., 64, 65-82 (2014) 